\title{
Analysis of the Level of Patient Satisfaction on the Quality of Service in the Inpatient Unit of RSUD dr. Soedomo Trenggalek 2021
}

\author{
Dony Sukardi ${ }^{1}$, Katmini
}

${ }^{1}$ RSUD dr. Soedomo Trenggalek

${ }^{2}$ Strada Indonesian Institute of Health Sciences

Email:

bilsa.doan@gmail.com

Received : October $4^{\text {nd }} 2021$

Accepted : October $15^{\text {rd }} 2021$

Published : November $27^{\text {th }} 2021$

\begin{abstract}
Regional General Hospital (RSUD) dr. Soedomo Trenggalek is one of the health organizations belonging to the Trenggalek district government. The number of patients each year at RSUD dr. Soedomo every year experiences erratic fluctuations, this refers to the quality of hospital services. Service performance at the dr. Soedomo still needs a lot of improvement because there are often complaints/complaints from patients and their families about the unsatisfied service received. Therefore, this research needs to be done so that it can improve the quality of service and the level of patient satisfaction. The type of research used in this research is quantitative descriptive with a population of all inpatients in the Seruni room at RSUD dr. Soedomo Trenggalek. The research sample is a total of 60 respondents taken by random sampling technique. Analysis of the data used is the percentage to determine the characteristics of the respondents, as well as multiple regression analysis to determine the effect of each independent variable on the dependent variable. The results obtained are Tangibles, reliability, responsiveness, assurance, empathy partially and simultaneously have a significant effect on the satisfaction of inpatients at RSUD $\mathrm{dr}$ Soedomo Trenggalek.variable Tangibles or physical facilities is the variable that has the greatest influence on the satisfaction of inpatients at RSUD Dr. Soedomo Trenggalek. It can be seen from the beta coefficient variable tangibles $\left(\mathrm{X}_{1}\right)$ which has a value of 0.388 , and variable assurance $\left(\mathrm{X}_{2}\right)$ has a value of the second largest, amounting to 0,313 compared to the beta coefficient else, namely empathy (X5) of 0.229 , responsiveness $\left(\mathrm{X}_{3}\right)$ equal to 0.207 , and va riabel reliability $\left(\mathrm{X}_{2}\right)$ of 0.169 .
\end{abstract}

Keywords: Quality of service, patient satisfaction, hospital

Copyright @ 2021 IIK STRADA Indonesia All right reserved.

This is an open-acces article distributed under the terms of the Creative Commons AttributionShareAlike 4.0 International License.

\section{INTRODUCTION}

The quality of health services is closely related to the structure (physical facilities, equipment, funds, health and non-health workers, and patients); process (hospital management, both interpersonal, technical and nursing services, all of which are reflected in medical and non-medical actions to patients); and outcomes. Quality aspects that can be used as indicators to assess the quality of hospital services are professional appearance (clinical aspect), efficiency and effectiveness, patient safety and satisfaction. Service quality is one of the duties and responsibilities of nurses as 
components who carry out these services, therefore nurses must be able to provide satisfactory service to every patient who visits, the quality of this service must be applied in accordance with the provisions and policies established for all health institutions, because the level of satisfaction is a benchmark of the quality of service of an institution.

In this era of globalization, patient satisfaction is one of the indicators of the success of health services in hospitals. Satisfaction is the emergence of a person's feelings of pleasure towards the work of others, his work, superiors and the work environment. Satisfaction will arise if expectations and reality equal or exceed the desired expectations. The emergence of a sense of satisfaction in a patient can be influenced by several things, namely: because the nature of the service received can provide a sense of satisfaction, the attitude of the officer who provides the health service itself and the form of communication and services provided (Azwar, A, 2010).

In Law no. 25 of 2009 concerning Public Services, it is explained that the community has the right to get quality services in accordance with the principles and objectives of service (Article 18). According to the Decree of the Minister for Empowerment of State Apparatus in 2003, public services are all service activities carried out by public service providers as an effort to fulfill the needs of service recipients as well as the implementation of statutory regulations. To achieve patient satisfaction, of course, by making efforts to provide health services in quality health institutions. In other words, officers and institutions provide good, effective, and efficient services (Djojodibroto, 2004).

People in using the services of a service must get satisfaction. The community really considers and sees the quality of service from medical services and chooses locations that are easily accessible. Most potential customers will turn out to be detectives, seeking evidence of competence, concern and integrity. Patient satisfaction is a fundamental need for health care providers. Satisfaction is important, when patients themselves seek health services, satisfaction will be a benchmark for future purchasing decisions (Woodshinn et al 1989). According to Pasolong (2007), there are five dimensions of service quality. The five dimensions, namely tangibles, responsiveness, assurance, and empathy. reliability, are characterized by the ability and reliability to provide appropriate and correct and reliable services. Tangibles, characterized by the provision of services in the form of physical office facilities, computerized administration, waiting rooms, information centers, and so on. Responsiveness, characterized by the ability to help and provide services quickly and accurately and responsive to consumer desires. Assurance, characterized by the ability and friendliness and courtesy of employees in ensuring consumer confidence. Empathy ischaracterized by a firm but attentive attitude from employees towards consumers.

Regional General Hospital (RSUD) dr. Soedomo Trenggalek is one of the health organizations belonging to the Trenggalek district government located in the city of Trenggalek, East Java. Hospital RSUD dr. Soedomo is a type c hospital that provides outpatient, inpatient, emergency and specialist services. Currently RSUD dr. Soedomo became one of the referral hospitals in handling Covid 19 patients. RSUD dr. Soedomo always improve the quality of service in order to achieve the expected target. Efforts are being made to increase the number of specialist doctors, expand the construction of hospital buildings and add service facilities. Patient complaints still often occur due to unsatisfactory services, the high cost of health services, very limited health facilities and infrastructure and other factors that affect patient satisfaction with the services provided by the hospital. Along with technological advances in the fields of medicine and health, the quality of quality services must also be improved. Customer or patient satisfaction is a very important thing that cannot be ignored by policy makers in the health sector.

The number of patients each year at RSUD dr. Soedomo every year experiences erratic fluctuations, this refers to the quality of hospital services. Service performance at the dr. Soedomo still needs a lot of improvement because there are often complaints / complaints from patients and their families about the unsatisfied service received.

\section{MATERIALS AND METHODS}

The research design used in this research is descriptive quantitative, namely trying to provide an accurate description or explanation of the problems studied, interpret and explain the existing data systematically based on the facts that appear or as they are. The researcher uses aapproach cross sectional which is used to study the dynamics of the correlation between risk factors and effects, by 
approaching, observing or collecting data all at once (point time approach). This study will analyze the quality of service in the Inpatient Unit of RSUD dr. Soedomo Trenggalek with patient satisfaction. The population in this study were inpatients in the Seruni room at RSUD dr. Soedomo Trenggalek with a total of 71 respondents with a sample of 60 respondents taken by random sampling technique. The data collected from filling out the respondent's questionnaire which is primary data is then processed and analyzed using percentage analysis to determine the characteristics of the respondents, multiple regression analysis to determine the effect of each independent variable on the dependent variable, and calculated $\mathrm{F}$ test to determine the effect of all independent variables. This research has been through ethical tests at IIK Strada Indonesia with number 2463/KEPK/VIII/2021.

\section{RESULTS}

\section{Characteristics of Respondents}

Based on the results of questionnaires that have been filled in by a number of respondents, it is known that the highest percentage of respondents' gender is $56.7 \%$ female (Table 1). The highest percentage of respondents is respondents aged 55 years and over as much as $33 \%$ (Table 2). Meanwhile, based on the level of education, the highest percentage indicates that $36.7 \%$ of respondents have graduated from high school/equivalent (Table 3). The percentage of respondents' characteristics by type of work shows that most of the respondents $(31.7 \%)$ have an entrepreneur type of work.

Table 1. Characteristics of Respondents by Gender

\begin{tabular}{|c|c|c|c|}
\hline \multirow{2}{*}{ No } & \multirow{2}{*}{ Gender } & \multicolumn{2}{|c|}{ Total } \\
\hline & & Number & Percentage \\
\hline 1 & Male & 26 & $43.3 \%$ \\
\hline 2 & Female & 34 & $56.7 \%$ \\
\hline & Total & 60 & $100 \%$ \\
\hline
\end{tabular}

Table 2. Characteristics of Respondents by Age

\begin{tabular}{|l|l|c|c|}
\hline \multirow{2}{*}{ No } & \multirow{2}{*}{ Age } & \multicolumn{2}{|c|}{ Total } \\
\cline { 3 - 4 } & & Number & Percentage \\
\hline 1 & $15-24$ years & 11 & $18.3 \%$ \\
\hline 2 & $25-34$ years & 7 & $11.7 \%$ \\
\hline 3 & $35-44$ years & 10 & $16.7 \%$ \\
\hline 4 & $45-54$ years & 11 & $18.3 \%$ \\
\hline 5 & $>55$ years & 21 & $35 \%$ \\
\hline \multicolumn{2}{|l|}{ Total } & 60 & $100 \%$ \\
\hline
\end{tabular}

Table 3. Characteristics of Respondents based on Education Level

\begin{tabular}{|l|l|c|c|}
\hline \multirow{2}{*}{ No. } & \multirow{2}{*}{ Last Education Level } & \multicolumn{2}{|c|}{ Total } \\
\cline { 3 - 4 } & & Number & Percentage \\
\hline 1 & Elementary School/Equivalent & 18 & $18.3 \%$ \\
\hline 2 & Junior & 22 & $36.7 \%$ \\
\hline 3 & $\begin{array}{l}\text { High School/EquivalentSenior } \\
\text { High School/Equivalent }\end{array}$ & 9 & $15 \%$ \\
\hline 4 & Universities/Academy & 60 & $100 \%$ \\
\hline \multicolumn{2}{|l|}{ Total } & & \\
\hline
\end{tabular}


Table 4.4 Characteristics of Respondents by Type of Work

\begin{tabular}{|c|c|c|c|}
\hline \multirow{2}{*}{ No } & \multirow{2}{*}{ Type of Work } & \multicolumn{2}{|c|}{ Total } \\
\hline & & Number & Percentage \\
\hline 1 & Student & 7 & $11.7 \%$ \\
\hline 2 & Farmer/labor & 15 & $25 \%$ \\
\hline 3 & Housewife & 6 & $10 \%$ \\
\hline 4 & Entrepreneur & 19 & $31.7 \%$ \\
\hline 5 & Civil Servant/Private & 8 & $13,3 \%$ \\
\hline 6 & Others & 5 & $8.3 \%$ \\
\hline \multicolumn{2}{|c|}{ Total } & 60 & $100 \%$ \\
\hline
\end{tabular}

2. Multiple Regression Test Analysis

Table 1 Results of linear regression analysis analysis of the effect of service quality on patient satisfaction levels

\begin{tabular}{|c|c|c|c|}
\hline $\begin{array}{c}\text { No } \\
.\end{array}$ & Variable & Sig & \multirow{2}{*}{ Constant } \\
\hline 1 & Tangibles & 0.388 & \multirow{2}{*}{-7.121} \\
\hline 2 & Reliability & 0.169 & \multirow{2}{*}{} \\
\hline 3 & Responsiveness & 0.207 & \\
\hline 4 & Assurance & 0.312 & \\
\hline 5 & Empathy & 0.229 & \\
\hline
\end{tabular}

a. Effect of Tangibles on patient satisfaction

From the results of the analysis, it is known that $\mathrm{t}_{\text {count }}=4.528$ and $\mathrm{t}$ table $=2.015$. This shows

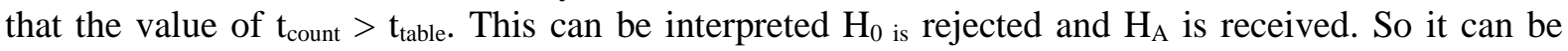
concluded that tangibles partially have a significant effect on the satisfaction of inpatients at RSUD dr. Soedomo Trenggalek. The effect ofvariables tangibles on patients was analyzed through regression testing and showed a positive effect, with a regression coefficient of 0.388 . This means that if thevariable tangibles increases by 1 unit, then inpatient satisfaction will increase by 0.388 units, assuming the independent variables $\mathrm{X}_{2}, \mathrm{X}_{3}, \mathrm{X}_{4}$, and $\mathrm{X}_{5}$ are constant.

b. Effect of Reliability on patient satisfaction

The results of the calculations that have been carried out show that the value of $t_{\text {count }}=2.159$ and $t_{\text {table }}=2.015$. This indicates that the value of $t_{t} t_{\text {table, }}$ so it can be interpreted $\mathrm{H}_{0}$ is rejected and $\mathrm{H}_{\mathrm{A}}$ is received or it can be concluded that the reliability is partially significant effect on patient satisfaction in dr. Soedomo Trenggalek. Thevariable reliability has a positive influence on inpatient satisfaction, with a regression coefficient of 0.169 . This means that if thevariable reliability increases by 1 unit, then inpatient satisfaction will increase by 0.169 units.

c. Effect of Responsiveness on patient satisfaction. The

data that has been analyzed shows the value of $t_{\text {count }}=2,624$ and $t_{\text {table }}=2,015$. This shows that the value of $\mathrm{t}_{\text {count }}>\mathrm{t}_{\text {table. }}$. It can iartikan $\mathrm{H}_{0}$ is rejected and $\mathrm{H}_{\mathrm{A}}$ is received. So it can be concluded that responsiveness partiallyhas a significant effect on inpatient satisfaction at RSUD dr. Soedomo Trenggalek. The responsiveness variable has a positive effect on inpatient satisfaction, with a regression coefficient of 0.207 . This means that if thevariable responsiveness increases by 1 unit, then inpatient satisfaction will increase by 0.207 units.

d. Effect of Assurance on patient satisfaction

The results of the analysis show that $t_{\text {count }}=2,937$ and $t_{\text {table }}=2,015$. This shows that the value of

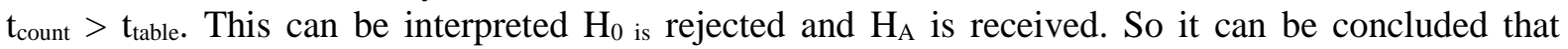
assurance partially has a significant effect on inpatient satisfaction at RSUD dr. Soedomo Trenggalek. Based on data analysis, it is known that thevariable assurance has a positive influence on inpatient satisfaction, with a regression coefficient of 0.312 . This means that if thevariable assurance increases by 1 unit, inpatient satisfaction will increase by 0.252 units.

e. Effect of Empathy on patient satisfaction

From the results of computer calculations, it is known that $t_{\text {count }}=2,372$ and $t_{\text {table }}=2,015$. This shows that the value of $t_{\text {count }}>t_{\text {table. }}$. This can be interpreted $\mathrm{H}_{0}$ is rejected and $\mathrm{H}_{\mathrm{A}}$ is received. So it can 
be concluded that empathy partially has a significant effect on inpatient satisfaction at RSUD dr. Soedomo Trenggalek.variable Empathy has a positive influence on inpatient satisfaction, with a regression coefficient of 0.229 . This means that if thevariable empathy increases by 1 unit, then inpatient satisfaction will increase by 0.229 units.

\section{F-test analysis}

From the ANOVA test obtained $\mathrm{F}_{\text {count }}$ is 109.243 with a significance level $(a)=5 \%$ and degrees of freedom nk-1 $=60-5-1=44$ then $\mathrm{F}_{\text {table }}(0.05 ; 54)=2.386$. From the calculation results obtained $F_{\text {count }}=38.331$ while $F_{\text {table }}=2.386$ means $F_{\text {count }}>F_{\text {table. }}$. This shows that there is a positive effect of service quality (tangibles, reliability, responsiveness, assurance, empathy) on the satisfaction of inpatients at RSUD dr. Soedomo Trenggalek. In this case means that $\mathrm{H}_{0}$ is rejected and $\mathrm{H}_{\mathrm{A}}$ is received, so it can be concluded that the quality of services that include tangibles, reliability, responsiveness, assurance, empathy simultaneously significant effect on patient satisfaction in dr. Soedomo Trenggalek.

\section{DISCUSSION}

Based on the results of multiple regression analysis, tangibles or physical evidence has the most significant effect on the satisfaction of inpatients at RSUD dr. Soedomo Trenggalek. Tangibles are the appearance of physical facilities, such as buildings and waiting rooms, the availability of parking spaces, cleanliness, neatness and comfort of the room, and the appearance of employees. Inpatients need the necessary physical facilities such as a clean and tidy inpatient room, adequate parking and waiting rooms, while the level of satisfaction with the facilities provided to patients varies greatly depending on the habits of the patient towards the physical facilities provided. ever felt.

According to Rifai (2005) if the patient feels comfortable with the services in the hospital, the comfort will affect the patient's satisfaction so as to encourage the patient to come back for treatment. This is in accordance with research conducted by Mariaty (2008), which states that the physical evidence variable has an effect on patient satisfaction. Research conducted by Rosita (2010) conducted at Herna Hospital Medan also shows that physical evidence has a real influence on patient decisions in assessing patient satisfaction.

Reliability or reliability has a significant effect on the satisfaction of inpatients at RSUD dr. Soedomo Trenggalek. Reliability is the ability to provide the promised service immediately, accurately, and satisfactorily. With the speed and accuracy of patient admission procedures, the speed of examination and treatment services for patients, the accuracy of the hospital service schedule and satisfactory services in dealing with patient diseases, patients will be satisfied with the reliability of the hospital.

The reliability of doctors and nurses in carrying out health services is an important point that affects patient satisfaction, because the reliability and skills of health workers in providing care will also leave a good impression on patients. Good service must be carried out in the right time and manner by the service provider (Pohan, 2007). The results of this study are also the same as the results obtained by Liharis (2010) and Hasibuan (2019 which states that reliability is one of the variables that affect patient satisfaction.

Based on the results of multiple regression analysis, responsiveness has a significant influence on inpatient satisfaction in RSUD dr. Soedomo Trenggalek. Responsiveness is the alertness of employees in helping customers and providing fast and responsive service. The alertness of the hospital medical team (doctors and nurses) in providing assistance to patients, clear service information so that it is easy to understand, speed of home staff In handling every transaction, the sense of understanding of the medical team towards the complaints of patients or patients' families which is carried out quickly and responsively will make customers feel cared for and appreciated so that they will be satisfied with the services provided by the hospital. According to Purwanto (2007), patient satisfaction is determined by several factors, including service ability, which includes speed, competence, and satisfactory handling of complaints for patients. The services provided by doctors and nurses with good responsiveness will also provide quick handling of patient complaints at any time.

Based on the results of multiple regression analysis, assurance has a significant effect on inpatient satisfaction at RSUD dr. Soedomo Trenggalek. Assurance is the scope of knowledge, ability, 
courtesy, and trustworthiness of employees. The existence of guarantees provided by the hospital such as the knowledge and ability of the medical team in establishing a disease diagnosis, the ability of the medical team to instill trust in patients, and friendliness, attention and courtesy in providing services make patients and their families believe in the hospital's ability to treat and serve patients so that they will feel satisfied with the services provided by the hospital. According to Pohan (2007), health services must be safe for both patients, service providers and the surrounding community. Quality health services must be safe from the risk of injury, infection, side effects caused by the health service itself, therefore it is better to develop a procedure that will ensure the safety of all parties.

Based on the results of multiple regression analysis, empathy has a significant effect on inpatient satisfaction at RSUD dr. Soedomo Trenggalek. Empathy is the individual attention that the hospital gives to patients, such as the ease of using the services offered, the ability to communicate to convey information, personal attention and understanding the needs of patients. Basically, people who are being treated or people who need other people to recover really need the attention of the people who are needed. Therefore, the attention of hospital employees, both medical and non-medical, really needs to be done to make customers (inpatients) satisfied. Parasuraman (2006) states that attention is part of the dimensions of service quality that affect service customer satisfaction. The results of this study are also in accordance with the results of research conducted by Deviyanti (2015) which states that there is an influence of attention on patient satisfaction.

The results of the $\mathrm{F}$ test analysis show that the service quality which consists ofvariables tangibles, reliability, responsiveness, assurance, empathy simultaneously has a significant influence on the satisfaction of inpatients at RSUD dr. Soedomo Trenggalek. This is because in the service business, service quality is an important thing and must be done as well as possible because the application of quality as the nature of product achievement or performance is a major part of the company's strategy in this case the hospital, in order to achieve sustainable excellence, both in leading the market and strategy for continued growth.

\section{CONCLUSION}

1. Tangibles, reliability, responsiveness, assurance, empathy partially have a significant effect on the satisfaction of inpatients at RSUD dr Soedomo Trenggalek. There is a significant tangibles effect on the satisfaction of inpatients at RSUD dr Soedomo Trenggalek with a $t_{\text {count }}$ of 4,528. There isinfluence of reliability a significanton the satisfaction of inpatients at Dr. Soedomo Trenggalek Hospital with a $t_{\text {count }}$ of 2,159 . There iseffect of responsiveness a significanton the satisfaction of inpatients at Dr. Soedomo Trenggalek Hospital with a $t_{\text {count }}$ of 2,624. There is a significant assurance effect on the satisfaction of inpatients at dr Soedomo Trenggalek Hospital with a $t_{\text {count }}$ of 2,937. There is a significant empathy effect on the satisfaction of inpatients at $\mathrm{dr}$ Soedomo Trenggalek Hospital with a $\mathrm{t}_{\text {count }}$ of 2,372.

2. Tangibles, reliability, responsiveness, assurance, empathy simultaneously (together) have a significant effect on the satisfaction of inpatients at RSUD dr Soedomo Trenggalek. This can be seen from the results of the $F$ test which shows that the $F_{\text {count }}(109.243)>F_{\text {table }}(2.386)$.

3. Variable Tangibles or physical facilities is the variable that has the greatest influence on the satisfaction of inpatients at RSUD dr. Soedomo Trenggalek. This can be seen from the beta coefficient of the variable tangibles which has a value of 0.388 , and the assurance has the second largest value, which is 0.313 compared to the other beta coefficients, namely empathy of 0.229 , responsiveness of 0.207 , and reliability variable of 0.169 .

\section{SUGGESTIONS}

Some suggestions that can be submitted based on the results of this study are as follows:

1. RSUD dr. Soedomo Trenggalek Hospital is expected to improve the quality of services provided to inpatients, considering thatvariables tangibles, reliability, responsiveness, assurance, and empathy play an important role in obtaining inpatient satisfaction. tall one.

2. RSUD dr. Soedomo Trenggalek is expected to increase the friendliness and care of medical staff (nurses) in dealing with inpatients. Doctors should be more punctual in their examinations and 
improve responses to inpatients quickly and precisely so that they can increase motivation for patients who want to recover.

3. RSUD dr. Soedomo Trenggalek is expected to improve the quality of human resources by providing training such as: excellent services and effective communication. It is hoped that nurses can provide information and education to patients regarding the treatment given.

\section{ACKNOWLEDGMENT}

Ideclare that to the best of my knowledge, in this thesis there is no scientific work that has been submitted by another person to obtain an academic degree at a university, and no work or opinion has been written or published by other people, except those who are quoted in writing in this manuscript and mentioned in the bibliography.

\section{CONFLICT OF INTEREST}

In this research there is no interest whatsoever concerning myself or with any other institution other than the Indonesian Strada Institute of Health Sciences, Kediri City.

\section{REFERENCE}

Azwar, A. 2010. Pengantar Adnministrasi Kesehatan. Tangerang : Binarupa Aksara

Deviyanti. 2015. Pengaruh Faktor Provider dan Karakteristik Konsumen Terhadap Kepuasan Peserta Jaminan Kesehatan Naional (JKN) di Ruang Rawat Inap Rumah Sakit Islam Malahayati. Skripsi FKM USU

Djojodibroto, R.D. 2004. Tradisi Kehidupan Akademik. Galangpress Group

Hasibuan, S.A., Zulfendri., Aulia, D. 2019. Pengaruh Kualitas Pelayanan dengan Kepuasan Pasien Di Rawat Jalan Penyakit Dalam RSUD Dr. Djoelham Binjai. Jurnal Kesmas Jambi $(J K M J), 3(1): 24-30$.

Liharris, Erida. Pengaruh Kualitas Pelayanan Terhadap Kepuasan Pasien Rawat Inap di RSU Bunda Thamrin Medan. Tesis FKM USU; 2010

Parasuraman, Zeithmal, VA and A. Berry.LL. 1998. A Multiple - Item Scale Measuring Consumer Perception Of Service Quality, Journal Of Retailing, $64: 12-35$.

Pasolong, Harbani. 2007. Teori Administrasi Publik. Alfabeta: Bandung

Pohan, Imbalo. 2007. Jaminan Mutu Pelayanan Kesehatan. Buku Kedokteran ECG: Jakarta

Purwanto, Agus Erwan dan Dyah Ratih Sulistyastuti. 2007. Metode Penelitian. Kuantitatif, Untuk Administrasi Publik, dan Masalah-masalah Sosial. Yogyakarta: Gava Media

Rifai, 2005. Pengaruh Persepsi Masyarakat Terhadap Pemanfaatan Pelayanan Pengobatan di Puskesmas Binjai Kota Tahun 2004, (Tesis), Medan : Program Magister Administrasi Kebijakan Kesehatan Program Studi Ilmu Kesehatan. Program Pasca Sarjana Universitas Sumatera Utara

Rosita S. 2010 Pengaruh Mutu Pelayanan Kesehatan Terhadap Loyalitas Pasien Rumah Sakit Herna. Jurnal FKM USU. 